East African Medical Journal Vol. 81 No. 12 December 2004

HBV, HIV CO-INFECTION AT KISUMU DISTRICT HOSPITAL, KENYA

A.E.O. Otedo, MBChB, MMed (Int. Med) (Nrb), Certificate in Gastroenterology (Tel-Aviv), Consultant Physician, Kisumu District Hospital, P.O. Box 4685, Kisumu, Kenya

\title{
HBV, HIV CO-INFECTION AT KISUMU DISTRICT HOSPITAL, KENYA
}

\author{
A. E. O. OTEDO
}

\begin{abstract}
Background: Patients with dual infection of $\mathrm{HBV}$ and HIV are increasingly being recognised. The two viruses, $\mathrm{HBV}$ and $\mathrm{HIV}$ share the same route of transmission and HBV is more efficiently transmitted than HIV. There is evidence that HBV will contribute significantly to continuing morbidity and mortality within the HIV infected population over the coming years. This is due to the widespread use/accessibility of the highly active anti-retroviral (HAART) drugs hence patients live longer. There are few published data in the tropical region on these patients especially in regions where HBV and HIV are endemic.

Objectives: To determine the prevalence of HBV, HIV co-infection in patients who presented with jaundice and the pattern of CD4 cell counts in these patients.

Design: A prospective, cross-sectional, descriptive study of all consecutive patients included in the study.

Setting: Medical wards, medical outpatient clinic and liver clinic, Kisumu District Hospital, Western Kenya.

Subjects: Five hundred and nineteen (261 females and 258 males) patients who had jaundice were screened for the study. One hundred and eighty five (110 males and 75 females) patients were excluded. Three hundred and thirty four patients $151(45.2 \%)$ males and $183(54.8 \%)$ females were included and completed the study between August 2002 and October 2003.

Main outcome measures: Socio-demographic data, HBsAg positive, HIV serology (positive or negative), CD4 cell counts, ALT and AST, IgG anti-HBc and IgM anti-HBc. Results: The age range was 7-76 years with a mean of $36( \pm 13)$ years. The mean age for males and females was $37( \pm 13)$ years and $35( \pm 12)$ years respectively. One hundred and seventy seven (53\%) had co-infection and 157(47\%) had HBV mono-infection. IgG anti-HBc and IgM anti-HBc were detected in $17(5 \%)$ and $317(95 \%)$ patients respectively. Of the 317 patients with IgM anti-HBc, $177(55.8 \%)$ had co-infection while $140(44.2 \%)$ had HBV mono-infection $(p=0.05)$. The overall mean CD4 cell count for the whole population was $391( \pm 314)$ cells $/ \mathrm{mm}^{3}$. The mean CD4 cell count for patients with co-infection was lower, $\left(120( \pm 112)\right.$ cells $\left./ \mathrm{mm}^{3}\right)$ than for patients with $\mathrm{HBV}$ monoinfection, $694( \pm 140)$ cells $/ \mathrm{mm}^{3}$. The transaminases were uniformly elevated in both groups with mean AST of $207( \pm 147)$ U/L and ALT of $356( \pm 177)$ U/L. In the co-infection and mono-infection groups, AST was $286( \pm 117) \mathrm{U} / \mathrm{L}$ and $306( \pm 175) \mathrm{U} / \mathrm{L}(\mathrm{p}=0.23)$ and is not statistically significant, and the ALT was 338 $( \pm 135) \mathrm{U} / \mathrm{L}$ and $375( \pm 213)$ $U / L$ respectively $p=0.05$ and the difference is statistically significant.

Conclusion: HBV and HIV co-infection is recognised in this region, which is endemic for both viral infections. The patients with dual infection had very low CD4 cell counts. This will influence the choice of highly active anti-retroviral therapy (HAART) in favour of Lamivudine containing combinations to cover the $\mathrm{HBV}$ infection.
\end{abstract}

\section{INTRODUCTION}

Viral hepatitis is a disease as old as the history of medicine, and was referred to by Hippocrates over 2000 years ago. However, HIV is a new disease. Both HBV and HIV are transmitted through blood, blood products and sexual activity and HBV is transmitted more efficiently (100x) than HIV (1-3). Dual infection with HBV and HIV is not a common feature lately.
Indeed, many patients with HIV may have co-infection with one or more hepatitis viruses (2). Adults with HIV infection who acquire acute HBV infection have a reduced likelihood of viral clearance and this is directly proportional to the level of CD4 cell count at the time of HBV acquisition (4). In contrast, adults without HIV infection develop a vigorous immune response and clear acute HBV infection in the majority of cases 
(> 90\%)(4). Reactivation of HBV in those who have previously lost detectable HBV surface antigen (HBsAg) may be associated with increasing immunosupression in the context of HIV infection $(5,6)$.

Western Kenya where Kisumu District hospital in particular is located is endemic for both HBV and HIV infections with a national prevalence rate of $25-35 \%$ (7) and $24.8 \%$ (8) respectively. Suffice it note that HBV infection was responsible for $70 \%$ of acute sporadic hepatitis in adults in Kenya (9). Hence, Kenya is endemic for HBV infection. The prevalence of $\mathrm{HBV} /$ HIV co-infection is poorly understood locally and is critical to patient care.

\section{MATERIALS AND METHODS}

Informed, signed consent was obtained from each subject (For < 18 year olds, signed by parent/ guardian). The study subjects responded to a standardised questionnaire. Both, pre-test and post-test counselling were done for patients whose HIV sero-status was not known. Post- test counselling was sustained for patients with known HIV positive status. Counselling was also done to screen for HBV infection.

\section{Figure 1}

Enrollment and inclusion/exclusion criteria of patients

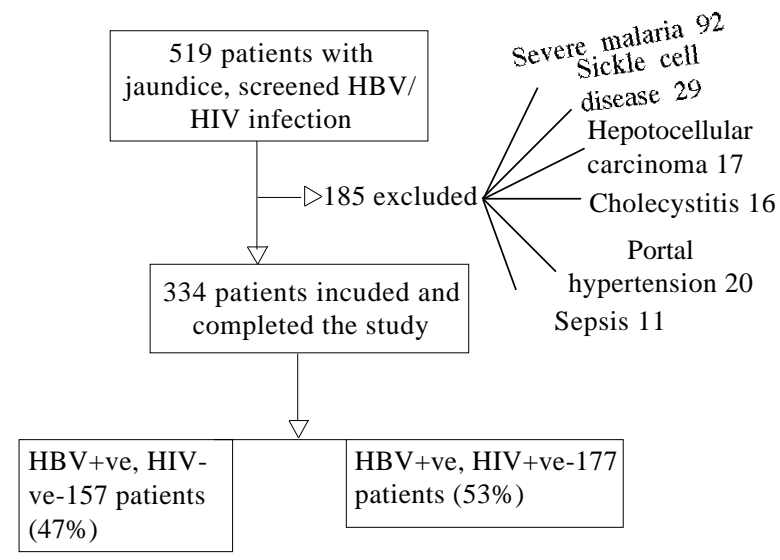

One hundred and eighty five patients (110 males and 75 females) were excluded because of hepatocellular carcinoma (17), severe malaria (92), sickle cell disease (29), sepsis (11), cholecystitis (16) and portal hypertension with hypersplenism (20) and were HBV negative. The remaining 334 patients (151 Males and 183 females) were recruited into the study conducted between August 2002 and October 2003. Some were patients with known HIV positive status on follow up at the medical outpatient clinic that developed jaundice.

Ten mls of whole blood was drawn under aseptic condition by venipuncture from cubital vein. Serum was separated and stored at $-30^{\circ} \mathrm{C}$. Two millilitres of whole blood was used to determine the CD4 cell count by facs (flow cytometry) count method. Sera were stored in dry ice in EDTA bottles. Enzygnost II (Organon Teknika GmbH D-69214 Eppelheim), a third generation kit with a sensitivity of $<0.15 \mathrm{IU} / \mathrm{ml}$ and specificity of $99.7-99.9 \%$ was used to analyze $\operatorname{IgM} / \operatorname{lgG}$ anti-HBc. Two millilitres of serum was used to determine the presence or absence of IgM-anti-HBc and $\mathrm{IgG}$ anti-HBc. Three millilitres of whole blood was used to determine AST, ALT by Technicon RA 1000 machine (Technicon RA systems No. SM-0034 D91 and No. SM 40137D91 1996). HBsAg was analyzed using reverse passive haemagglutination assay (RPHA). ALT and AST was analyzed using Hepanostica uni-form II kit (Organon Teknika, SA, F94267 Fresnes Cedex), a third generation micro-Elisa kit with a specificity of $99.8-99.9 \%$ and analytical sensitivity of 0.10 $0.20 \mathrm{IU} / \mathrm{ml}$. The presence of liver dysfunction was defined as elevated AST or ALT ( $>36 \mathrm{U} / \mathrm{L}$ and $>40 \mathrm{U} / \mathrm{L}$ ) respectively. HIV test was done using ELISA method with a sensitivity and specificity of $99.9 \%$ and $98.9 \%$ respectively.

Intervention: All the subjects included in the study were managed appropriately as either out or in patients for their symptoms vis-a-vis (fever, malaise, jaundice, and ARV-antiretroviral therapy (for those who could afford). The combination of ARV used was (Effervirenz or Viramune + Lamivudine and Zidovudine).

\section{RESULTS}

The results were expressed as percentages, mean $( \pm \mathrm{SD})$ and bar charts. Three hundred and thirty four patients (151 males and 183 females) were included in the study. The age range was $7-76$ years with a mean of $36( \pm 13)$ years. The mean age of the patients with only HBsAg positive was $34( \pm 14)$ years while those with co-infection, was $38( \pm 12)$ years $(\mathrm{P}=$ $0.0005)$. The age difference was statistically significant. The mean age for males was $37( \pm 13)$ years and females $35( \pm 12)$ years, $(\mathrm{P}=0.15)$ which was not statistically significant. $117(53 \%)$ of all patients were co-infected, while 157(47\%) were HBsAg positive/HIV negative $(\mathrm{P}=0.005)$.

All the 334 patients were jaundiced and had HBsAg detected. IgG anti-HBc were detected in 17 patients who were all HBsAg positive and HIV negative. IgM anti $\mathrm{HBc}$ were detected in 317 patients; of these, $140(44.2 \%)$ were HIV negative and 177 (55.8\%) were HIV positive, $(\mathrm{P}=0.0001)$ indicating significant statistical difference between patients with HBV monoinfection and co-infection.

The mean CD4 cell count for all the patients in the study was $391( \pm 314)$ cells $/ \mathrm{mm}^{3}$ and the CD4 cell count for patients with only HBsAg positive was 695 $( \pm 140)$ cells $/ \mathrm{mm}^{3}$ while for patients with co-infection was $120( \pm 112)$ cells $/ \mathrm{mm}^{3}(\mathrm{P}<0.005)$, the difference in the means was statistically significant.

Serum AST and ALT levels for all patients was $207( \pm 147) \mathrm{U} / \mathrm{L}$ and $356( \pm 177) \mathrm{U} / \mathrm{L}$ respectively. The mean (sd) AST for HBsAg positive /HIV negative group was $306( \pm 175) \mathrm{U} / \mathrm{L}$ and that of the co-infected group was $286( \pm 117) \mathrm{U} / \mathrm{L}, \mathrm{P}=0.23$, which was not statistically different. The mean (sd) ALT for HBsAg positive/HIV negative group was significantly higher at $375( \pm 213) \mathrm{U} / \mathrm{L}$, than that of the co-infected group of $338( \pm 135) \mathrm{U} / \mathrm{L}(\mathrm{P}=0.05)$. 
Figure 2

Proportion of study patients with HBV/HIV co-infection by age group and gender

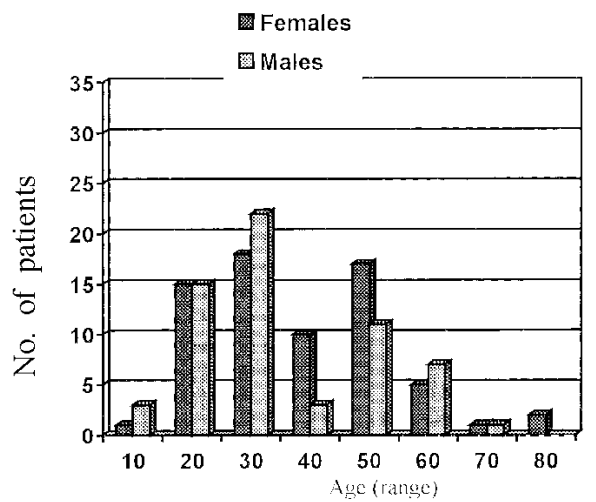

Figure 3

Proportion of study patients with HBV only infection by age group and gender

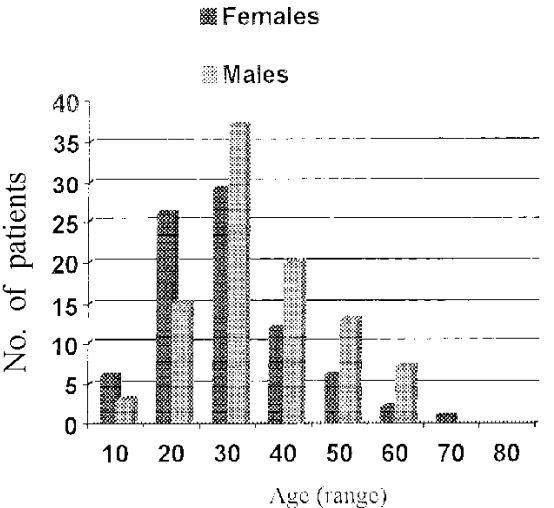

Table 1

Biodata, HBsAg positive, co-infection (HBsAg and HIV positive)

\begin{tabular}{lllll}
\hline & $\begin{array}{l}\text { HBV+, HIV } \\
\text { negative }\end{array}$ & HBsAg+,HIV+ & Total & P - value \\
\hline $\begin{array}{l}\text { No. of patients } \\
\text { Mean age (yrs) }\end{array}$ & 157 & 177 & 334 & 0.005 \\
\hline
\end{tabular}

Table 2

Mean CD4 cell count, AST and ALT concentrations

\begin{tabular}{|c|c|c|c|c|}
\hline & $\begin{array}{l}\mathrm{HBV}+\mathrm{ve} / \\
\text { HIV negative }\end{array}$ & $\begin{array}{l}\text { Co-infection } \\
\text { HBV/HIV positive }\end{array}$ & $\begin{array}{l}\text { Total population } \\
\text { of study }\end{array}$ & P-value \\
\hline AST (U/L) Mean $( \pm \mathrm{SD})$ & $306(175)$ & 286 (117) & 207 (147) & 0.23 \\
\hline ALT (U/L) Mean $( \pm S D)$ & $375(213)$ & $338(135)$ & $356(177)$ & 0.05 \\
\hline CD4 cells $/ \mathrm{mm}^{3}$ Mean $( \pm \mathrm{SD})$ & $695(140)$ & $120(112)$ & $391(314)$ & $<0.005$ \\
\hline
\end{tabular}

Table 3

Proportion and sero-status of $H B V, \operatorname{Ig} G$, IgM antibodies of the study patients

\begin{tabular}{lllll}
\hline & $\begin{array}{l}\text { HBV+ve, HIV } \\
\text { negative }\end{array}$ & $\begin{array}{l}\text { Co-infection } \\
\text { HBV/HIV positive }\end{array}$ & Total & P-value \\
\hline IgM-anti-HBc & 140 & 177 & 317 & 0.013 \\
IgG-anti-HBc & 17 & - & 17 & - \\
\hline
\end{tabular}

\section{DISCUSSION}

Despite the advances in its management, $\mathrm{HBV}$ is still the 9th leading course of death worldwide including USA (1). HBV infection is quite common and debilitating in both the developing and developed world (1). Effects of HIV on HBV have been depicted as increased HBV DNA, reduced ALT and increased prevalence of liver cirrhosis (2). The co-infection of HBV and HIV has been suspected to accelerate the progression of liver disease.
Indeed immunity impairment due to HIV infection can be the cause of a higher rate of HBV replication with less intense liver damage and less effective immune response to HBV infection (1). Acute HBV infection in an HIV infected patient may have deleterious effects and in some cases, the development of fulminant hepatic failure (FHF). This worsens the morbidity and mortality in co-infected patients (2).

In this study, the prevalence of HBV, HIV coinfection in patients with jaundice during the study 
period was $53 \%$, while that of patients who were HBsAg positive but HIV negative was $47 \%$. All the $177(53 \%)$ patients with co-infection tested positive for $\mathrm{IgM}$ anti-HBc, none had IgG anti-HBc. One hundred and forty $(42.0 \%)$ patients tested positive for only HBsAg and were HIV negative. IgG anti-HBc was detected in only $17(5 \%)$ of patients all of whom were HBsAg positive/HIV negative. Studies done have also shown an increased liver morbidity and mortality with dual infection of HBV and HIV compared to HBV mono-infection and associated accelerated loss of antiHBs antibody $(10,15)$.

About $64.35 \%$ of patients presenting with jaundice to this hospital during the study period had HBV infection. This is quite common. Of these HBV positive patients, $53 \%$ were HIV positive. These observations reflect very significant morbidity due to $\mathrm{HBV}$ and or HIV infection. HBV and HIV infections may need to be looked for in two of three patients presenting with jaundice in this environment. HBV is re-activated in HIV positive patients due to depressed cell mediated immunity. This causes predominant hepatocytolysis and worsens the liver disease $(6,11,12)$. A study done in Mexico showed that co-infection with HBV and HIV is high among homosexuals, which was also associated with severe liver disease (13-16).

The dual infection by HBV and HIV leads to more aggressive liver disease with the two viruses interacting in poorly defined ways to increase the rate of hepatic fibrosis $(13,17)$. The lower AST/ALT may actually be a reflection of poor functional liver reserve. Some studies have also shown that with HIV infection, the patients are more likely to develop chronic HBV infection (4), lower rate of spontaneous $\mathrm{HBcAg}$ seroconversion (5) and re-activation of $\mathrm{HBV}$ disease $(6,11,18)$.

The patients in this study who had co-infection of HBV and HIV had lower CD4 cell counts 120 $( \pm 112)$ cells $/ \mathrm{mm}^{3}$ compared to $695( \pm 140)$ cells $/ \mathrm{mm}^{3}$ in patients who had HBV mono-infection, $\mathrm{p}<0.005$. All the $177(53 \%)$ patients with co-infection also tested positive for IgM anti-HBc. This would suggest a possibility of re-activation of $\mathrm{HBV}$ infection or new infection in these HIV positive patients especially in this endemic setting.

Indeed, this compares to a study done in Poland which demonstrated that co-infection of HBV (IgM anti-HBc positive) and HIV was associated with low CD4 cell count (14). This implies a relatively longer or severe HIV infection and immune compromise and may enhance re-activation of $\mathrm{HBV}$ infection in the presence of HIV (16). This observation raises questions about the possible nature (may be molecular or immune-based) of potential mutual interactions between HBV and HIV infections (19-21). It was observed in Romania that HBV infection intensified the immunological disorders in those with dual infection $(10,20,22)$.
ALT and AST were uniformly elevated in both groups of patients. This manifest liver/hepatocyte damage due to HBV, HIV or both viruses in the coinfected cases. HIV may modify the natural history of HBV infection. There was a high prevalence of HBV infection in the co-infected than immunocompetent patients in this study population. This posses a major public health implication of potential transmission especially to $\mathrm{HBV}$ close contacts. HIV infection seems to facilitate either reactivation of (or new) HBV infection. With HBV and HIV co-infection, HBV replication is higher; ALT levels are lower and there are lower rates of seroconversion to antihepatitis B e (anti-HBe) and $\mathrm{s}$ anti-bodies (anti-HBs) (23). Indeed, recent assessment of HBV serological patterns in co-infected patients showed that these patterns may significantly evolve over time, whatever the initial serological status (24). This suggests that a periodic re-evaluation of HBV serological status in HIV infected patients is necessary $(24,25)$.

\section{ACKNOWLEDGEMENTS}

To the Medical Superintendent and $\mathrm{MOH}$ Kisumu District Hospital for allowing the data to be published. Laboratory in-charge Kisumu District Hospital and cellPath Laboratory Kisumu for the serological and virological tests. The clinical officers and nurses in the medical wards who assisted in collecting the blood samples.

\section{REFERENCES}

1. Chloe, L. Thio, Hepatitis B virus infection in the HIV infected patients. WHO and CDC proceedings at DDW 2003; May 2003, Orlando, Florida.

2. Colin and Laizizi. Effects of HIV on HBV infection. Amer. J. Gastroenterology. 1999; 1:117-121

3. Blaine, H.F. Hepatitis B. Extended abstracts from the IX international symposium on viral hepatitis and liver disease. Rome, 1996; 21 st $_{-2} 5^{\text {th }}$ April: Pg. 1.

4. Budsworth, N.J., Cooper, D.A., and Donovan, B. The influence of human immunodeficiency virus type 1 infection on the development of the Hepatitis B virus carrier state. J. Infect. Dis. 1991; 163:1138-1140.

5. Kraagsaard, K., Homan, C., Pedersen, C. et al. High incidence of hepatitis $\mathrm{B}$ virus infection and evolution of chronic hepatitis B infection in patients with advanced HIV infection. J. Acquir. Immune. Defic. Synd. 1991; 4:416-420.

6. Vento, S., di Perli, G., Luzzatti, R. et al. Clinical reactivation of hepatitis $\mathrm{B}$ in anti-HBs -positive patients with AIDS. Lancet. 1989; 1:332-333.

7. Okoth, F. A. Viral hepatitis. East Afr. Med. J. 1996; 73:308-312

8. AIDS in Kenya, NASCOP Nyanza Province AIDS and STI control programme, province and district estimates of HIV infection based on sentinel surveillance in pregnant women. 2003.

9. Greenfield, C., Shah, M. V., Karayiannis, P. Aetiology of acute sporadic hepatitis in adults in Kenya. J. Med. Virol. 1984; 14:357-362.

10. Thio, C .L., Seaberg, E. C., Skolasky, R. et al. HIV, Hepatitis $\mathrm{B}$ virus and risk of liver related mortality in the multicenter cohort study (MACS). Lancet. 2002; 360:1921-1926. 
11. Ciutica, I., Bastides, F., Besnier, M., Barin, F. and Choutel, P. Hepatitis B virus reactivation in patients infected with HIV. Bateriol. Viruso. Parazitol epidemiol. 1997; 42:59-63.

12. Colin, J. F., Cazals-Hatem, D., Loriot M. A. et al. Influence of human immunodeficiency virus infection on chronic hepatitis B in homosexual men. Hepatology. 1999; 29:1306-1310.

13. Juanez-Figueroa, L. A., Uribe-salas F. J. Conde-Glez, C. J. et al. HBV markers in men seeking human immunodeficiency virus antibody testing in Mexico City. Sex trans. Dis. 1997; 24:211-217.

14. Smiatacz, T. and Zielinska, W. Does hepatitis B virus or hepatitis $\mathrm{C}$ virus infection influence CD4 cell count in HIV positive individuals? Arch. Immunol. Ther. Exp. 1996; 44:335-343.

15. Puoti, M., Spinetti, M., Ghazzi, A. et al. Mortality for liver disease in patients with HIV infection: a cohort study. J. Acquir. Immune. Defic. Syndr. 2000; 24:211-217.

16. Francisci, D., Balldelli, F., Papili, R. et al. Prevalence of HBV, HDV and HCV hepatitis markers in HIV positive patients. Eur. J. Epidemiol. 1995; 11:123-126.

17. Cropley, I. and Main, J. Co-infection of HBV and HIV. Best practice and research in clinical Gastroenterology . 2000; 14:265-275.

18. Vandercum, B., Cornu, C., Galla, J.L. Reactivation of hepatitis B virus in a previously immune patient with human immunodeficiency virus infection. Eur. J. Clin. Microbiol. Infect. Dis. 1990; 9:701-702.
19. Lincoln, D., Petoumenos K. and Dore, G. J. Hepatitis B in the human immunodeficiency virus-infected patient. Epidemiology, natural history and treatment. Semin. Liv. Dis. 2003; 23:125-136.

20. Gilson R.J., Hawkins E.A., Beecham M. R., et al. Interactions between HIV and hepatitis B virus in homosexual men. AIDS. 1997; 11:597-606.

21. Kim, A.Y., Chung, R.T. and Polsky, B. HIV and hepatitis $\mathrm{B}$ and $\mathrm{C}$ co-infection. Pathogenic interactions, natural history and therapy. AIDS Clin. Rev. 2001; 2:263-306.

22. Antipa, C., Ruta, S., Cernescu, C., Copelovici, Y., Strauss, I. and Iosipenco, M. Immunological disorders of increased severity in children with AIDS associated with hepatitis B and C virus infections. Romanian J. Virology. 1995; 46:3-8.

23. Puoti, M, Airoldi, M, Bruno, R. et al. Hepatitis B virus co-infection in human immunodeficiency virus infected individuals. AIDS Rev. 2002; 4:27-35.

24. Piroth, L, Birquet, C., Vergen, M. et al. The evolution of hepatitis B virus serological patterns and the clinical relevance of isolated antibodies to hepatitis B core antigen in HIV infected patients. J. Hepatol. 2002; 36:681-686.

25. De Luca, A., Bugarini, R., Lepri, A. et al. Co-infection with hepatitis viruses and outcome of initial anti-retroviral regimens in previously naive HIVinfected subjects. Arch. Intern. Med. 2002; 162:2125-2132. 